\title{
Student-centered College English Teaching based on Moodle Platform
}

\author{
Xiaoling Zhang ${ }^{1, \text { a }}$ \\ ${ }^{1}$ Maoming Polytechnic, Maoming, Guangdong, 525000 \\ a email
}

Keywords: Moodle Platform, College English Teaching, Learning Quality

\begin{abstract}
In traditional college English listening and speaking teaching, teachers teach mainly in the form of a single teaching, teaching content boring, unable to motivate students to learn in English heard on the progress. Currently, research on college English listening and discussion of teaching in education, conduct extensive and diverse forms of teaching methods and teaching forms are increasingly used to hear teaching practice, however, the teaching effect is still unsatisfactory. Based on college English visual Moodle platform integration that make up the traditional teaching listening and speaking teaching deficiencies, multimedia, networking and foreign language teaching combining teacher-led, student-centered, in the modern network platform, text, sound, graphics, image, animation and other integrated functions, to maximize the mobilization and stimulate students' enthusiasm and initiative, thereby enhancing the efficiency of student teaching.
\end{abstract}

\section{Introduction}

The rapid development of economic globalization today, international exchanges become more frequent, common English as an international language of communication has been widely used in various fields. Social demand for English talent growing, businesses are able to communicate in English need a lot of comprehensive talent. This college English teaching, especially teaching college English listening and speaking put a higher demand. Therefore, to improve the English listening and speaking teaching strengthen the students' English communication ability, to adapt to the social development of great significance. However, the current traditional indoctrination heard teaching, not only teaching a single structure, and the lack of interaction between teachers and students, so that students learn to hear gradually lose interest. Although the education sector through a variety of means and methods of teaching college English listening and speaking have been studied, but the teaching effect achieved is unsatisfactory. With the development of the global information age, the multimedia network technology has become more developed, and applied to college English teaching, for carrying out teaching and improve students' interest in learning has brought great convenience. Therefore, how modern information technology and network technology to support the use of modern computer intelligence tools, says the audiovisual integration, with students interested in building a network platform to simulate scenarios for teaching, teaching English listening and speaking face to solve problems develop learners 'self-learning ability to improve learners' language skills and the use of the ability to construct knowledge, thereby increasing between teachers and students, cooperation and exchange between life and life, is the starting point and destination of this study.

\section{Moodle Platform Overview}

Moodle platform is "Australian teacher Dr. Martin Dougiamas Constructivism Education Theory for hosting based on the development of a free, open source course management system is a software package for building Internet-based courses and web sites." It has been widely in the world use. Moodle is both a noun and a verb, when it is used as a noun, is "Modular Object-Oriented Dynamic Learning Environment" acronym, translated as "dynamic learning environment modular object-oriented"; as a verb, it is an expression of the development and creation. An important feature of Moodle platform is the teaching ideas of social constructivism as a theoretical basis, to promote teamwork, cooperative learning to their existing experience and to jointly construct new 
knowledge. Moodle platform through the assistance network to help teachers and students to achieve in the case without the constraints of time, you can always interactive learning. In order to improve students' self-learning ability, this paper builds a platform for practice. A variety of teaching activities to be carried out inside and outside the classroom, such as unit tests, assignments, work presentation and discussion of cooperation can be achieved through the Moodle platform. You can say "Moodle platform for teachers and students to provide a better teaching and online virtual learning environment for students and teachers set up a communication bridge." Thus, the module functions by Moodle platform for teaching, not only to facilitate the teaching and learning, but also to develop students' self-inquiry, collaborative learning and other capacities.

\section{University Teaching English Situation Investigation and Problems Analysis}

Currently, most colleges and universities during the teaching of English heard on all means of modern teaching equipment, and achieved some gains and improve. I heard engaged in teaching, and more use of "multimedia, network technology" as a platform, to change the traditional tape recorder, tape teaching tool narrowness and limitations, will hear boring material into intuitive visual richness colorful graphics to enrich the student's imagination, will listen, speak, look, and other elements of integration, to mobilize the students' interest in learning English, to stimulate students' motivation to learn, to improve the students' attention in the classroom. Upon hearing the teaching, emphasizing the use of audio materials to train students listening and speaking ability, students are required to accept the voice signals at the same time, to hear the material to understand and remember, then processed for their information and output feedback. Although all heard teaching has its own characteristics, to improve students' listening and speaking ability has made no small contribution, but now the teacher-centered, over-reliance on classroom teaching mode, there are still some drawbacks.

First, the students heard that teaching is not enough in-depth understanding of English listening and speaking English generate psychological fear, afraid to speak English, lack of listening and speaking environment caused by long-term do not speak English, did not understand English vicious cycle. Secondly, a single mode of teaching in English listening class, many teachers are using "Listen - do the exercises - to answer." This teaching model allows students to gradually lose interest in listening class, it affects their learning efficiency. This teacher chalk and talk teaching model center, the course content is determined by the teacher, the teacher on the podium like actresses monologue, the students in the audience as spectators, passively receive information transmitted teacher, learning the lack of autonomy. Over time, in such a teaching mode, suppressing the students' enthusiasm and initiative. In addition, the traditional college English listening class, the lack of interaction between teachers and students. Most teachers restricted materials, in order to complete the arduous task of teaching, to finish the work in class only scripted, whether the students understand the content taught not take into account; in the limited class time, no time to give students timely help and guide. Class, the students can only follow on teaching schedule to go, no time to think and understand, let alone teachers and students to communicate and discuss.

\section{Moodle Platform of College English Teaching Exploration}

First, before the start of the course, organizing experimental class using Moodle platform organized special training seminars. To help students understand how to implement the platform in Moodle Integration of College English Listening and Speaking Teaching students to solve operational problems encountered in this process. It requires them to log in Zunyi Normal College campus network platform to participate in this course Moodle online learning. And register on the platform, after they go on the web to find the course, participation in University Teaching Learning English Video. Students entering the program interface, read the column will announce specific learning step, students can follow the steps listed in the self-study, student teachers know what the current level of mastery of the course. In order to better carry out the teaching, the self-study phase, students can also use the discussion board and chat template Moodle platform for teachers and 
students to consult their own existence in the process of self-doubt, through the Moodle platform between students and life and life there is doubt and confusion interact, through discussion, not only to deepen students' course of study impression, but also to expand the breadth and depth of knowledge of students.

Class, teachers must first deal with the students in the case of self-evaluation and analysis phase, in explaining the teaching content, the use of video, images, sound, animation and text to show the form of teaching course content, to provide students with the locale. In the presentation and explanation of the teaching content is at the same time. The importance of English learning context, by voice and video and other multimedia data, enhance student interest in learning, so that the classroom forms more abundant, while encouraging students to learn to imitate the teachers to guide students in the teaching process bold opening to imitate, and to participate in the students' scenario simulation, enhanced between teachers and students, exchange and collaboration between life and life, improve student learning motivation and interest in sex, it can play a student of subjective power, in a harmonious learning atmosphere, the establishment of a teacher-led, student as the main mode of learning.

To enable students to better understand their mastery of knowledge, the author designed the after-school test knowledge points, conduct leak filled, through testing, I can understand the students' learning progress and learning to give students usually results . Students learning platform login time, the number of activities and participation can be displayed through the Moodle platform, we can keep abreast of student learning through the platform, and to learn as usual record achievement assessment indicators; each student participating in a study after the event, the author through the platform to score, which is usually an important indicator of assessment; these results with the above data, half of the final mark and the author of a comprehensive student, after the end of the semester gives students more scientific and fair consolidated results, I heard the reaction of the real level of the students, to encourage students to participate more actively in the course of the study, the formation of a virtuous cycle.

\section{The Key Issues on College English Teaching of Moodle Platform}

Be teaching English listening and speaking can be a wealth of teaching material uploaded to the platform through the platform for students to study independently, and help teachers to solve this contradiction outstanding teaching task teaching time is short but heavy on the Moodle platform. However, teachers in the choice of teaching content, its content can not be confined to textbooks should as much as possible to provide students with the knowledge of their proportionate interest in the material, to achieve "standard", "Ben" Virtue, to achieve a "standard" seeking " the "teaching objectives. Here the "standard" refers to the teaching of the entire teaching content and exercises; where "this" refers to after the completion of all course content and practice retained in the student's inner wisdom and ability. Therefore, in the Moodle platform, it is necessary to select teachers for students' intensive listening, "the material, but also the actual situation of the students, and there are plans to guide students to choose" Extensive Listening "materials, finishing only with the pan, quality combined with the amount of science it is possible to achieve the level of English listening and speaking leap.

On the Moodle platform listening comprehension in English, although the emphasis on student autonomy inquiry learning, but that does not mean reducing the role of teachers to guide students in learning; rather teachers should play a leading role in the teaching activities focus on students learning process supervision and guidance. In teaching practice, I have learned that students are more willing to participate in discussions relating to the participation of teachers, teachers' recommendations and feedback on student recognition, will be encouraged to mobilize their learning enthusiasm and initiative. Discuss teachers should be actively involved in their spare time to study the lead to carry out collaborative interactive activities, and students together to explore the best way of learning for each part. Teachers should encourage students to participate in the discussion, in the process of learning to establish emotional communication with students to help some students build self-confidence, and tap their potential, promote their invest more time and 
energy to learn English, and get better in English Learning Effect.

I heard that English teaching platform based on Moodle emphasize that community learning, through the creation of a real language environment for students on the Moodle platform, guide students' ability to communicate on a common platform and collaboration, students of the spirit of cooperation and collaboration to solve problems. Thus, on the platform of curriculum design, teacher determined according to the teaching content and teaching objectives, create a task context, to take group-type activities, students are grouped, each set clear tasks allow students to refine and distribution within the Group task in the design of learning activities, the teacher should choose some need for mutual assistance in the completion of activities for students to collaborate with each other by way of the completion of these learning activities, learning outcomes to summarize and reflection among the last members of the group, at the same time between the team and the team should learn from each other on the effects of scientific and objective evaluation of each other to share the results, learn from each other, each other to lift the doubts, and finally summed up for their own learning, for further cooperation in the future and lay a good foundation. In the teaching process, teachers should encourage students to collaborate, stimulate their enthusiasm to promote understanding and communication between team members. So that students in the process of cooperation and exchanges in the relaxed and happy to complete the learning task, absorbing the advantages of other students at the same time, improve their own shortcomings, common progress and improvement in the cooperation.

\section{Conclusion}

At present, many colleges and universities put a lot of manpower and financial resources to buy expensive software learning system in order to build information campus, but the effect is not ideal. Since most teachers on the front line are not proficient computer skills, which brings information for the construction of the campus great obstacles, not only failed to bring help to the students, but also waste a lot of money. However, Moodle platform as a free open source software can not only save costs, and less demanding on computer skills, simple operation, eliminating the barriers to technology for teachers and students to bring factors. This is also more and more universities choose Moodle platform for an important reason.

\section{References}

[1] Anderson, A. \& T. Lynch. Listening. Cambridge: Cambridge University Press, 1998.

[2] B. Kumaravadivelu. Macro-strategies for Language Teaching [M]. New Haven: Yale University Press. 2003.

[3] David Gardner \& Lindsay Miller. Establishing Self-Access: Fromtheory to practice [M]. Cambridge: Cambridge University Press.1999.

[4] Little, D. Learner Autonomy: Definition, Issues and Problems [M]. Dublin: Authentik, 1991. 